\title{
PENINGKATAN AKTIVITAS SISWA PADA PEMBELAJARAN JARAK JAUH (PJJ) MATA PELAJARAN KIMIA MENGGUNAKAN PLATFORM GOOGLE CLASSROOM
}

\section{INCREASING STUDENTS' ACTIVITIES IN DISTANCE LEARNING ON CHEMISTRY MATERIAL USING GOOGLE CLASSROOM PLATFORM}

\author{
Tri Sejati \\ SMAN 1 Tarakan \\ trisejati002@gmail.com
}

\begin{abstract}
Abstrak
Selama Pembelajaran Jarak Jauh (PJJ) banyak kendala yang dihadapi oleh guru terutama dalam hal membangun dan mendokumenkan aktivitas siswa, baik kehadiran maupun evaluasi. Salah satu LMS pada PJJ adalah google classroom. Penggunaan google classroom dalam pembelajaran dapat merekam berbagai aktivitas siswa dan guru selama PJJ. Hal ini ditunjukkan dalam hasil penelitian tindakan kelas yang dilakukan terhadap siswa kelas XII MIPA 5, SMAN 1 TARAKAN tahun pelajaran 2020/2021 bahwa google classroom sebagai kelas maya saat PJJ dapat digunakan untuk mengetahui aktivitas siswa dan guru selama pembelajaran berlangsung melalui observasi aktivitas guru dan siswa. Dari hasil observasi yang dilakukan pada siklus 1 dan siklus 2 menunjukkan aktivitas siswa mengisi daftar hadir tepat waktu pada siklus 1 sebesar $61 \%$ kategori sedang meningkat menjadi $75 \%$ pada siklus 2 dengan kategori tinggi. Aktivitas siswa mengumpulkan tugas atau penilaian secara tepat waktu pada siklus 1 meningkat dari $64 \%$ menjadi $80 \%$ pada siklus 2 dengan kategori tinggi. Sedangkan aktivitas guru dari $82 \%$ pada siklus 1 meningkat menjadi $95 \%$ pada siklus 2 dari kategori tinggi menjadi sangat tinggi. Dengan diperoleh data peningkatan aktivitas guru dan siswa dalam pembelajaran menunjukkan bahwa google classroom dapat digunakan sebagai media pembelajaran yang dapat merekam aktivitas siswa SMAN 1 Tarakan kelas XII MIPA 5 selama pembelajaran dengan kategori tinggi dan aktivitas guru dengan kategori sangat tinggi.
\end{abstract}

Kata Kunci: google classroom, aktivitas siswa, aktivitas guru

\begin{abstract}
During Distance Learning (PJJ), teachers face many obstacles, especially in terms of building and documenting student activities, both attendance and evaluation. One of the LMS at PJJ is google classroom. The use of google classroom in learning can record various activities of students and teachers during PJJ. This is shown in the results of classroom action research conducted on students of class XII MIPA 5, SMAN 1 TARAKAN 2020/2021 academic year that google classroom as a virtual class when PJJ can be used to determine student and teacher activities during learning through observation of teacher and student activities. From the results of observations made in cycle 1 and cycle 2 showed that the activity of students filling out the attendance list on time in cycle 1 was $61 \%$, the category was increasing to $75 \%$ in cycle 2 with the high category. Student activity collecting assignments or assessments in a timely manner in cycle 1 increased from $64 \%$ to $80 \%$ in cycle 2 with the high category. Meanwhile, teacher activity from $82 \%$ in cycle 1 increased to $95 \%$ in cycle 2 from high to very high category. By obtaining data on the increase in teacher and student activity in learning, it shows that google classroom can be used as a learning medium that can record the activities of students of SMAN 1 Tarakan class XII MIPA 5 during learning with a high category and teacher activities with a very high category.
\end{abstract}


Keywords: google classroom, student activities, teacher activities

How to Cite: Sejati, T. (2021). Peningkatan aktivitas siswa pada Pembelajaran Jarak Jauh (PJJ) mata pelajaran kimia menggunakan platform google classroom. Al asma: Journal of Islamic Education, 3(1), 134-144.

\section{PENDAHULUAN}

Kelas selama Pembelajaran Jarak Jauh (PJJ) diharapkan seperti dalam kelas tatap muka dimana guru dapat mengetahui aktivitas siswa diantaranya kehadiran dan terkumpulnya hasil belajar siswa, oleh karenanya selama PJJ diperlukan pengelolaan kelas yang baik. Menurut Rusman (2010), kegiatan guru dalam mengelola kelas meliputi kegiatan pengaturan siswa, pengaturan tempat belajar, pemilihan bentuk kegiatan, pemilihan media pembelajaran, penilaian. Sebagai indikator keberhasilan guru dalam menciptakan kondisi yang memungkinkan dengan melakukan pengelolaan kelas dapat dilihat pada proses belajar mengajar berlangsung secara efektif. Selain pengelolaan kelas, aktivitas pembelajaran merupakan prinsip atau asas yang sangat penting dalam interaksi saat pembelajaran sebab pada prinsipnya belajar adalah berbuat untuk mengubah tingkah laku. Tidak ada belajar kalau tidak ada aktivitas. Dalam kegiatan belajar, subyek didik atau siswa harus aktif berbuat. Dengan kata lain, bahwa dalam belajar sangat diperlukan adanya aktivitas (Sardiman, 2003).

Aktivitas belajar merupakan suatu kegiatan yang dilakukan untuk menghasilkan perubahan pengetahuan, nilai sikap dan keterampilan pada siswa sebagai latihan yang dilakukan secara sengaja (Hasmiati \& Mustami, 2017). Menurut Hamalik (2002) aktivitas belajar merupakan suatu kegiatan yang dilakukan untuk memperoleh pengetahuan, pemahaman dan keterampilan serta perilaku lainnya termasuk sikap dan nilai. Aktifnya siswa selama proses belajar mengajar merupakan salah satu indikator adanya keinginan atau motivasi siswa untuk belajar. Siswa dikatakan memiliki keaktifan apabila ditemukan ciri-ciri perilaku seperti: sering bertanya kepada guru atau siswa lain, mau mengerjakan tugas yang diberikan oleh guru, mampu menjawab pertanyaan, senang diberi tugas belajar, dan lain sebagainya. Semua ciri perilaku tersebut pada dasarnya dapat ditinjau dari dua segi yaitu segi proses dan dari segi hasil. Sardiman (2003) menyatakan bahwa dalam kegiatan belajar, siswa harus aktif berbuat. Siswa dituntut menggali pengetahuannya sendiri, sedangkan guru hanya sebagai fasilitator yakni mengatur dan mengorganisasi siswa sehingga proses belajar dapat berjalan dengan baik. Selanjutnya Rusman (2015) menyebutkan ciri-ciri aktivitas yang termasuk belajar ada 4 yaitu: terjadi secara sadar, bersifat fungsional, positif dan aktif serta bertujuan dan terarah. Berdasarkan pendapat di atas dapat disimpulkan bahwa aktivitas belajar meliputi aktivitas positif siswa yang dilakukan secara sadar dan sengaja pada saat pembelajaran guna memperoleh pengetahuan dan pengalaman belajar yang baik.

Berdasarkan hasil kuesioner terhadap guru SMAN 1 Tarakan terkait teknik pembelajaran selama PJJ menunjukkan bahwa dari 53 responden 90,7\% guru menggunakan teknik pembelajaran daring, 9,3\% luring dan 14\% blanded learning, sedangkan media pembelajaran yang pernah digunakan guru selama PJJ adalah 79,1\% menggunakan google classroom, 86\% menggunakan whatsApp, 25,6\% menggunakan telegram, 51,2\% menggunakan zoom meeting, 32,6\% menggunakan google meeting dan 
11,6\% menggunakan opsi yang lain. Hasil kuesioner tersebut menunjukkan bahwa guru yang melaksanakan teknik pembelajaran daring lebih banyak menggunakan media whatsApp sebagai penyampai materi maupun penilaian. Beberapa guru menggunakan media telegram. Keluhan beberapa guru bahwa penggunaan media whatsApp dan telegram sangat menyita memori penyimpanan gadget guru dan terkadang guru menghapus beberapa file siswa guna mengurangi beban penyimpanan. Hal ini berakibat histori siswa selama PJJ tidak dapat didokumenkan dan sulit ditelusuri. Seperti pada pembelajaran kimia baik materi ajar, daftar hadir, dan tugas siswa menggunakan ruang penyimpanan yang besar dalam smartphone. Karakteristik pembelajaran kimia terutama KD. 3.5 dan 3.6 mengenai Elektrokimia lebih menekankan pada pemahaman konsep atau mengkonstruksikan pengetahuan yang dipelajari oleh karenanya diperlukan suatu media pembelajaran atau LMS guna menyampaikan pembelajaran dimana siswa leluasa beraktivitas di dalamnya.

Kelas pada pelaksanaan PJJ dikenal dengan kelas maya. Dalam kelas maya ini, diharapkan siswa dapat beraktivitas dengan leluasa. Media yang memenuhi unsur-unsur pembelajaran seperti peserta didik, materi ajar, daftar hadir dan evaluasi sangat diperlukan. Media pembelajaran yang direkomendasikan tentunya media pembelajaran yang dapat mengakomodir berbagai bentuk materi ajar yang bervariasi seperti video, file maupun alat evaluasi yang dapat memunculkan hasil belajar peserta didik secara realtime, diantaranya adalah google classroom, Schology, dan Microsoft teams. Salah satu LMS yang sering digunakan dalam PJJ adalah google classroom. Penggunaan media pembelajaran seperti google classroom diharapkan dapat merekam berbagai aktivitas siswa dan guru selama pembelajaran tanpa memenuhi memori gadget. Google classroom merupakan inovasi yang paling menarik dari google karena merupakan produk yang dibuat untuk mendampingi pendidik dan peserta didik dalam melaksanakan kegaiatan belajar mengajar. Google classroom sesungguhnya dirancang untuk mempermudah interaksi pendidik dan peserta didik dalam dunia maya (Sutrisna, 2018). Aplikasi ini memberikan kesempatan kepada guru untuk mengeksplorasi gagasan keilmuan yang dimilikinya kepada siswa, untuk menciptakan pembelajaran yang aktif dan efektif.

Penelitian yang pernah dilakukan terkait perekaman peningkatan aktivitas siswa saat pembelajaran menggunakan google classroom selama PJJ penulis belum menemukan. Namun dari beberapa penelitian yang telah dilakukan penulis mengkaji bahwa google classroom dapat merekam berbagai aktivitas positif terkait pembelajaran. Seperti dilakukan oleh Rahmanto dan Bunyamin (2020) dalam penelitiannya terkait efektifitas media pembelajaran google classroom yang diterapkan terhadap mahasiswa menunjukkan bahwa google classroom efektif digunakan pada mata pelajaran praktikum administrasi yang dilihat dari meningkatnya hasil belajar mahasiswa melalui tugas dan kuis yang diberikan setiap harinya. Penelitian efektifitas penggunaan google classroom juga dilakukan oleh Sabran dan Subara (2019), dilakukan terhadap jurusan teknik elektronika mata kuliah multi media pembelajaran. Pada penelitiannya mengukur beberapa indikator. Beberapa indikator yang diperoleh dari hasil penelitian berdasarkan analisis data secara deskriptif dengan pendekatan kuantitatif instrumen angket penelitian diperoleh aspek interaksi pembelajaran menunjukkan cukup efektif dengan tingkat kecenderungan $66,10 \%$, Aspek evaluasi pelaksanaan pembelajaran google classroom menunjukkan kategori cukup efektif dengan kecenderungan sebesar 69,01\%, Aspek penyampaian atau 
metode penyampaian pembelajaran google classsroom menunjukkan kategori cukup efektif dengan tingkat kecenderungan 75\%. Nurfayanti dan Nurbaeti (2019) melakukan penelitian terhadap mahasiswa semester V program studi Pendidikan Matematika FKIP Universitas Muslim Maros tentang pengaruh Pembelajaran Google Classroom dalam Pembelajaran Analisis Real terhadap Motivasi Mahasiswa. Berdasarkan tes hasil belajar dan lembar angket motivasi belajar terhadap 32 orang mahasiswa menunjukkan bahwa terdapat pengaruh signifikan motivasi belajar mahasiswa setelah diterapkan pembelajaran google classroom. Skor rata-rata hasil belajar dan respon mahasiswa masing-masing sebesar 78,31 yang berada pada kategori tinggi dan 83,72\% yang berada pada kategori sangat baik.

Berdasarkan uraian di atas, penulis sangat tertarik untuk melakukan penelitian tindakan kelas terkait penggunaan aplikasi google classroom pada pembelajaran kelas maya saat PJJ guna merekam peningkatan aktivitas siswa pada konsep Elektrokimia pada siswa kelas XII MIPA 5 SMAN 1 Tarakan tahun pelajaran 2020/2021."

\section{METODE PENELITIAN}

Penelitian ini merupakan Penelitian Tindakan Kelas (PTK) dengan desain penelitian model Kurt Lewin. Pada pelaksanaannya terdiri dari 2 siklus masing-masing siklus terdiri dari 3 kali pertemuan. Penelitian dilakukan di SMAN 1 Tarakan, Jalan Ki Hajar Dewantara No. 18. Tarakan, Kalimantan Utara. Populasi dalam penelitian ini adalah seluruh kelas XII MIPA yang terdiri dari 5 kelas, yakni XII MIPA 1, XII MIPA 2, XII MIPA 3, XII MIPA 4, XII MIPA 5 . Sampel penelitian adalah siswa kelas XII MIPA 5 yang terdiri dari 15 siswa laki-laki dan 21 siswa perempuan. Penelitian dilaksanakan dari bulan Agustus hingga bulan Oktober 2020 pada semester ganjil tahun pelajaran 2020/2021. Penelitian ini dilakukan selama tiga bulan, dimulai dari persiapan, pelaksanaan, hingga penyusunan laporan hasil penelitian.

Teknik pengumpulan data adalah dengan observasi menggunakan lembar observasi aktivitas siswa dalam mengisi daftar hadir dan mengerjakan tugas serta observasi aktivitas guru dalam pembelajaran dari pendahuluan, kegiatan inti dan penutup sesuai Rencana Pelaksanaan Pembelajaran (RPP). Dalam penelitian ini, peneliti didampingi oleh seorang observer dari teman sejawat yang diundang dalam google classroom sebagai guru.

Penelitian ini menggunakan teknik analisis deskriptif kualitatif, yaitu suatu model penelitian yang bersifat menggambarkan kenyataan atau fakta sesuai dengan data yang diperoleh dengan tujuan untuk mengetahui aktivitas siswa selama proses pembelajaran. Analisis ini dihitung dengan menggunakan statistik sebagai berikut:

Persentase aktivitas belajar setiap peserta didik diperoleh dengan rumus:

$$
P=\frac{\sum \text { siswa aktif }}{\sum \text { siswa }} \times 100 \%
$$

(sumber : Purwanto 2012:202)

Jumlah siswa aktif dalam penelitian ini dari rumus di atas merupakan jumlah kehadiran siswa pada kategori sangat aktif dan aktif. Pedoman kriteria keaktifan siswa pada pembelajaran menurut Arikunto (2007:18) sebagaimana tertera pada Tabel 1. 
Tabel 1. Kriteria Keaktifan Siswa

\begin{tabular}{cc}
\hline Capaian & Kriteria \\
\hline $79 \%-100 \%$ & Tinggi \\
$51 \%-74 \%$ & Sedang \\
$25 \%-50 \%$ & Rendah \\
$0 \%-24 \%$ & Sangat rendah \\
\hline
\end{tabular}

Keaktifan siswa diamati dari aktifitas mengisi daftar hadir yang dibagikan dalam google classroom dan ketepatan waktu mengumpulkan. Persentase aktivitas guru diperoleh dengan rumus:

$$
N=\frac{\sum \text { skor aktifitas }}{\sum \text { skor maksimal }} \times 100 \%
$$

(sumber : Purwanto 2012:202)

Kriteria aktifitas guru sebagai tertera pada tabel 2.

Tabel 2. Kriteria Aktifitas Guru

\begin{tabular}{cc}
\hline Aktifitas \% & Kriteria \\
\hline $86-100$ & Sangat baik \\
$76-85$ & Baik \\
$60-75$ & Cukup \\
$55-59$ & Kurang \\
$\leq 54$ & Kurang sekali \\
\hline Sumber : (Purwanto, 2010)
\end{tabular}

Indikator keberhasilan dalam penelitian ini apabila aktivitas siswa dan aktifitas guru di setiap siklusnya mengalami peningkatan.

\section{HASIL DAN PEMBAHASAN}

Penelitian Tindakan Kelas ini dalam pelaksanaannya terdiri dari 2 siklus, dan masing-masing siklus terdiri dari 3 kali pertemuan. Langkah pelaksanaan penelitian tiap siklus diawali dengan perencanaan dilanjutkan pelaksanaan tindakan. Pada proses pelaksanaan tindakan observer melaksanakan tugasnya untuk mengobservasi keaktifan siswa dan guru selama proses belajar berlangsung.

\section{Hasil Observasi Siklus 1}

Hasil Observasi ketepatan waktu mengisi daftar hadir

Tabel 3. Hasil Observasi Keaktifan Siswa dalam Mengisi Daftar Hadir Siklus 1

\begin{tabular}{ccc}
\hline \multirow{2}{*}{ Pertemuan } & \multicolumn{2}{c}{ Jumlah Siswa Kategori } \\
\cline { 2 - 3 } & Aktif & Kurang Aktif \\
\hline 1 & 21 & 15 \\
2 & 22 & 14 \\
3 & 24 & 12 \\
Rerata & 22 & 14 \\
Persen (\%) & $61 \%$ & $39 \%$ \\
\hline
\end{tabular}

Dari tabel 3 nampak bahwa terjadi peningkatan jumlah siswa yang aktif mengisi daftar hadir dari pertemuan 1 hingga pertemuan 3 pada siklus 1, 21 siswa yang aktif meningkat menjadi 22 dan 24 siswa pada pertemuan 2 dan 3. Rerata jumlah siswa aktif pada siklus 1 sebesar 61\% dengan kategori sedang. 
a. Hasil Observasi Ketepatan Waktu Pengumpulan Tugas Siklus 1

Tabel 4. Hasil Observasi Ketepatan Waktu Mengumpulkan Tugas Siklus I

\begin{tabular}{ccc}
\hline Pertemuan & $\begin{array}{c}\text { Jumlah peserta didik tepat waktu } \\
\mathbf{( 0 8 . 2 0 - 0 8 . 3 0 )}\end{array}$ & $\begin{array}{c}\text { Jumlah peserta didik } \\
\text { Terlambat }(\mathbf{> 0 8 . 3 0 )}\end{array}$ \\
\hline Pertemuan 1 & 14 & 20 \\
Pertemuan 2 & 27 & 9 \\
Pertemuan 3 & 27 & 9 \\
Rerata & 23 & 13 \\
Persen (\%) & $64 \%$ & $36 \%$ \\
\hline
\end{tabular}

Dari tabel 4 nampak bahwa ketepatan waktu siswa mengumpulkan tugas dalam classroom meningkat dari pertemuan 1 hingga pertemuan 3 dari 23 siswa pada pertemuan 1 menjadi 27 siswa pada pertemuan 2 dan 3. Rerata siswa mengumpulkan tugas tepat waktu sebesar 23 siswa atau 64\% dengan kategori sedang.

b. Hasil Observasi Aktivitas Guru saat Mengajar dalam Classroom

Tabel 5. Hasil Observasi Aktivitas Mengajar Guru Siklus I

\begin{tabular}{llccc}
\hline \multirow{2}{*}{ No } & \multirow{2}{*}{ Kategori } & Pertemuan 1 & Pertemuan 2 & Pertemuan 3 \\
& & & & \\
\hline 1 & Pendahuluan & 12 & 12 & 14 \\
2 & Kegiatan pembelajaran & 11 & 13 & 13 \\
3 & Penutup & 10 & 12 & 12 \\
\hline Jumlah skor & 32 & 37 & 39 \\
Persen (\%) & $75 \%$ & $84 \%$ & $89 \%$ \\
\hline
\end{tabular}

Dari tabel 5 menunjukkan aktivias guru meningkat dari pertemuan 1 hingga pertemuan 3, sehingga rerata aktivitas guru mencapai rereta $83 \%$ dengan kategori baik.

Berdasarkan hasil pengamatan aktivitas siswa terhadap pengisian daftar hadir pada google classrooom yang disajikan pada tabel 3, secara rerata dari 36 siswa, sebanyak 22 siswa atau 61\% hadir tepat waktu yakni pada pukul 07.30-07.50. Sedangkan sebanyak 14 siswa hadir di kelas terlambat. Hal ini dikerenakan adanya beberapa masalah yakni siswa bangun kesiangan, dan sebagian kecil sinyal tempat siswa pada saat PJJ kurang baik. Keterlambatan siswa mengisi daftar hadir atau hadir dalam kelas pada google classroom berakibat masih banyak siswa yang mengalami keterlambatan pada aktivitas mengumpulkan tugas. Hal ini nampak pada tabel 2. Dari 36 siswa sebanyak 23 siswa atau $64 \%$ yang mengumpulkan penugasan atau penilaian tepat waktu yakni pada pukul 08.2008.30. Sedang aktivitas guru pada siklus 1 dengan kategori baik. Oleh karenanya pada siklus 2 dilakukan kembali pembelajaran dengan memberikan motivasi kepada semua siswa, agar aktivitas siswa dalam mengisi daftar hadir atau hadir di kelas dan mengumpulkan tugas dapat meningkat. 
2. Hasil Observasi Siklus 2

a. Hasil Observasi ketepatan waktu mengisi daftar hadir

Tabel 6. Hasil Observasi Keaktifan Siswa dalam Mengisi Daftar Hadir Siklus 2

\begin{tabular}{ccc}
\hline \multirow{2}{*}{ Pertemuan } & \multicolumn{2}{c}{ Jumlah Siswa Kategori } \\
\cline { 2 - 3 } & Aktif & Kurang Aktif \\
\hline 5 & 28 & 8 \\
6 & 29 & 7 \\
Rerata & 25 & 11 \\
Persen (\%) & 27 & 9 \\
\hline
\end{tabular}

Dari tabel 6 menunjukkan bahwa pada siklus 2 terjadi peningkatan aktifitas siswa dalam mengisi daftar hadir pada pertemuan 4 ke pertemuan 5 , namun terjadi penurunan pada pertemuan 6 . Hal ini dikarenakan faktor jaringan dari beberaa siswa yang kurang lancar. Pada siklus 2 persentasi siswa aktif sebesar 75\% dengan kategori tinggi.

b. Hasil Observasi Ketepatan Waktu Mengumpulkan Tugas Siklus 2

Tabel 7. Hasil Observasi Ketepatan Waktu Mengumpulkan Tugas Siklus 2

\begin{tabular}{lcc}
\hline Pertemuan & $\begin{array}{l}\text { Jumlah peserta didik tepat waktu } \\
(\mathbf{0 8 . 2 0 - 0 8 . 3 0 )}\end{array}$ & $\begin{array}{l}\text { Jumlah peserta didik } \\
\text { Terlambat (> 08.30) }\end{array}$ \\
\hline Pertemuan 1 & 30 & 6 \\
Pertemuan 2 & 30 & 6 \\
Pertemuan 3 & 33 & 3 \\
Rerata & 31 & 5 \\
Persen (\%) & $86 \%$ & $14 \%$ \\
\hline
\end{tabular}

Dari tabel 7 nampak bahwa ketepatan waktu siswa mengumpulkan tugas dalam classroom meningkat dari pertemuan 3 dan 4 jumlah siswa 30 menjadi 31 siswa pada pertemuan 6. Rerata siswa mengumpulkan tugas tepat waktu sebesar 31 siswa atau $86 \%$ dengan kategori tinggi.

c. Hasil Observasi Aktivitas Guru saat Mengajar dalam Classroom

Tabel 8. Hasil Observasi Aktivitas Mengajar Guru Siklus I

\begin{tabular}{clccc}
\hline \multirow{2}{*}{ No } & \multirow{2}{*}{ Kategori } & \multicolumn{3}{c}{ Jumlah skor/pertemuan } \\
\cline { 3 - 5 } & & Pertemuan 1 & Pertemuan 2 & Pertemuan 3 \\
\hline 1 & Pendahuluan & 15 & 15 & 15 \\
2 & Kegiatan pembelajaran & 14 & 15 & 15 \\
3 & Penutup & 12 & 12 & 12 \\
Jumlah skor & 41 & 42 & 42 \\
Persen (\%) & $93 \%$ & $95 \%$ & $95 \%$ \\
\hline
\end{tabular}

Dari tabel 8 menunjukkan aktivias guru pada siklus 2 dalam tiap pertemuannya menunjukkan peningkatan hingga pertemaun 6 sebesar 95\% dengan kategori sangat baik. 


\section{Rerata Hasil Observasi Siklus 1 dan Siklus 2}

a. Rerata Aktifitas SiswaMengisi Daftar Hadir Siklus 1 dan Siklus 2

Hasil observasi keaktifan siswa dalam siklus I dan siklus 2 disajikan pada tabel 9.

Tabel 9. Hasil Observasi Keaktifan Siswa dalam Mengisi Daftar Hadir Siklus 1 dan Siklus 2

\begin{tabular}{cccc}
\hline \multirow{2}{*}{ Siklus } & \multicolumn{2}{c}{ Jumlah siswa tiap kategori } & \multirow{2}{*}{ \% siswa aktif } \\
\cline { 2 - 3 } & Aktif & Cukup aktif & \\
\hline \multirow{2}{*}{1} & 22 & 14 & $61 \%$ \\
2 & 13 & 13 & $75 \%$ \\
& 27 & 9 & \\
\hline
\end{tabular}

Dari tabel 9 nampak bahwa aktifitas siswa dalam mengisi daftar hadir pada siklus 1 dengan kategori aktif sebanyak 22 siswa, kurang aktif sebanyak 14 siswa. Pada siklus 2 mengalami peningkatan jumlah siswa dengan kategori aktif dengan jumlah 30 siswa, dan terjadi penurunan jumlah siswa kurang aktif. Persentase siswa aktif pada siklus 1 sebesar $61 \%$ dengan kategori sedang meningkat menjadi 75\% pada siklus 2 dengan kategori tinggi. Peningkatan aktivitas siswa dalam mengisi daftar hadir atau hadir dalam classroom disajikan pada Gambar 1 berikut.

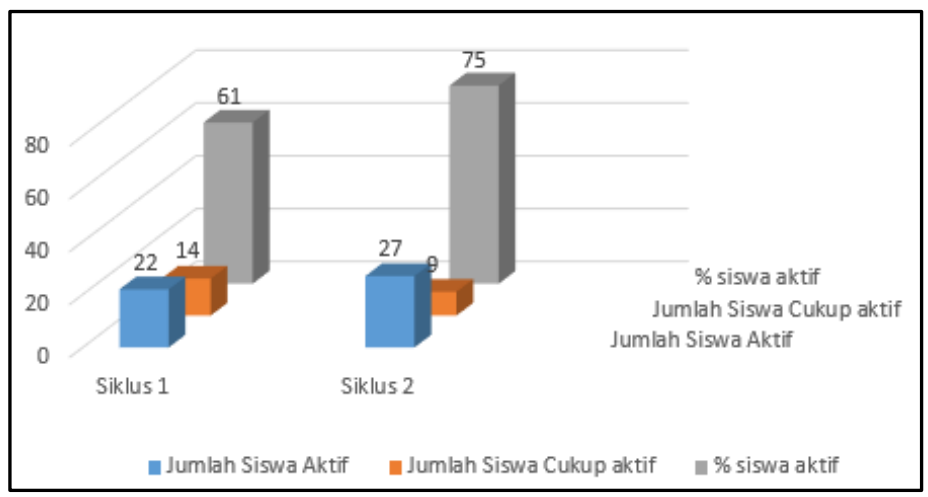

Gambar 1. Grafik Peningkatan Aktivitas Siswa dalam Mengisi Daftar Hadir Siklus 1

b. Aktivitas Siswa Mengumpulkan Hasil Belajar

Rekapitulasi ketepatan waktu siswa dalam mengumpulkan hasil belajar pada siklus 1 dan siklus 2 dapat dipresentasikan pada tabel 10 .

Tabel 10. Rekapitulasi Ketepatan Waktu Siswa dalam Mengumpulkan Hasil Belajar pada Siklus I

\begin{tabular}{cccc}
\hline Siklus & \multicolumn{2}{c}{ Jumlah siswa mengumpulkan tugas } & \% siswa mengumpulkan \\
\cline { 2 - 3 } & Tepat waktu & Terlambat & \\
tugas tepat waktu
\end{tabular}

Dari tabel 10 nampak bahwa aktivitas siswa dalam mengumpulkan tugas tepat waktu mengalami peningkatan dari siklus 1 hingga siklus 2. Rerata aktivitas siswa mengumpulkan tugas tepat waktu pada siklus 1 sebesar $64 \%$ dengan kategori sedang meningkat pada siklus 2 menjadi $86 \%$ dengan kategori tinggi.

Peningkatan aktivitas siswa dalam ketepatan waktu mengumpulkan tugas disajikan dalam grafik pada gambar 2 . 


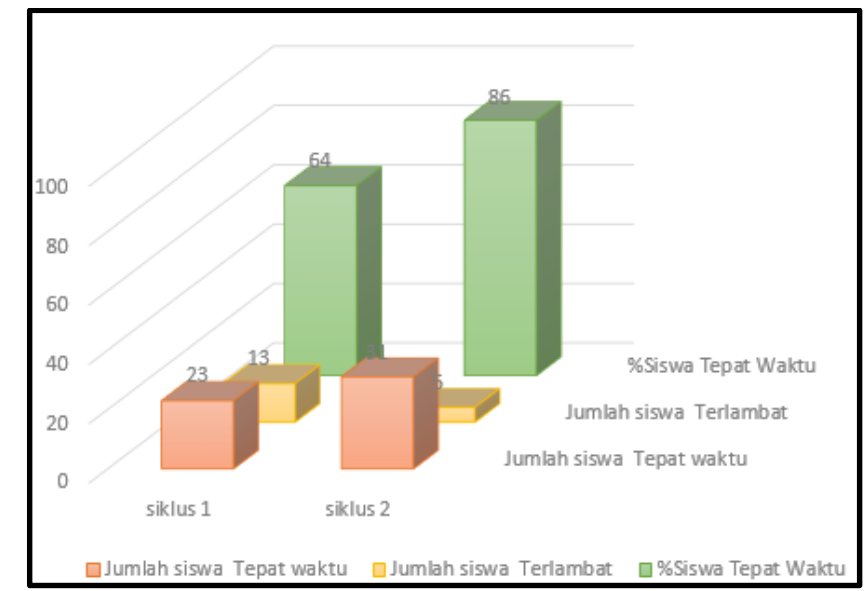

Gambar 2. Grafik Aktifitas Siswa Mengumpulkan Tugas pada Siklus I dan Siklus 2

3. Hasil observasi aktivitas guru pada siklus 1 dan siklus 2 disajikan pada tabel 11 berikut ini.

Tabel 11. Rekapitulasi Aktifitas Guru dalam Google Classroom

\begin{tabular}{ccc}
\hline Siklus & Jumlah Skor Aktivitas Guru & \% Aktivitas Guru \\
\hline 1 & 36 & $82 \%$ \\
2 & 42 & $95 \%$ \\
\hline
\end{tabular}

Dari tabel 11 nampak bahwa aktivitas guru pada pembelajaran dalam google classroom mengalami peningkatan pada siklus 1 sebesar $82 \%$ menjadi $91 \%$ siklus 2 . Aktifitas guru dalam pembelajarn pada siklus 1 dengan kategori baik meningkat menjadi sangat baik pada siklus 2. Peningkatan aktivitas guru dari siklus 1 ke siklus 2 disajikan pada Gambar 3.

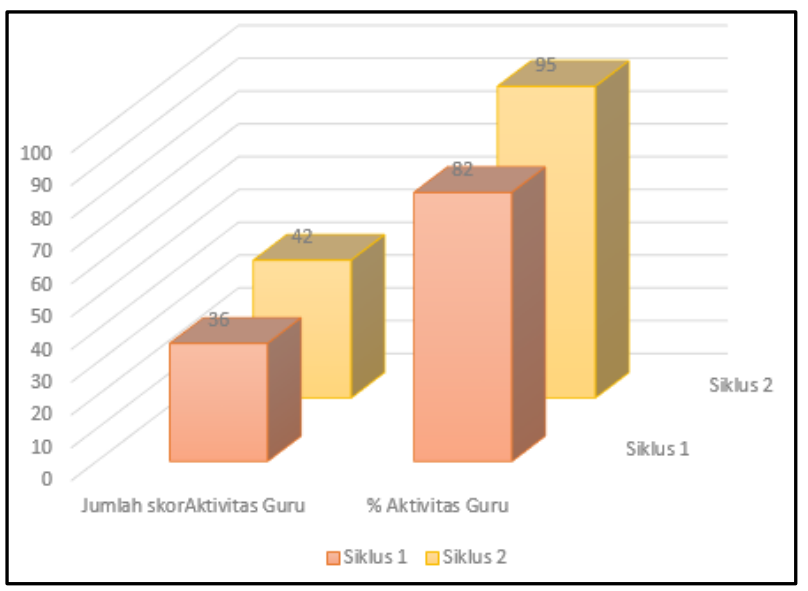

Gambar 3. Grafik Peningkatan Aktivitas Guru pada Siklus 1 ke Siklus 2

Hasil observasi pada siklus 2 terhadap aktivitas siswa dalam mengisi daftar hadir yang disajikan pada tabel 6 menunjukkan terjadinya peningkatan jumlah siswa yang mengisi daftar hadir secara tepat waktu. Demikian juga aktivitas siswa dalam mengumpulkan tugas tepat waktu meningkat pada akhir siklus 2. Hal ini seiring dengan meningkatnya aktivitas guru saat mengajar di dalam kelas yang juga mengalami peningkatan hingga akhir siklus 2. Peran guru dalam memotivasi siswa dalam belajar dan mengisi daftar hadir atau hadir di kelas tepat waktu yang dilakukan saat pembelajaran memberikan dampak positiv terhadap meningkatnya aktivitas siswa dalam pembelajaran yakni mengisi daftar hadir dan mengumpulkan tugas secara tepat waktu. Hal ini selaras 
dengan pendapat Sanjaya dikutip oleh Musriana (2019) bahwa guru sebagai motivator dimana guru mampu membimbing dan memberi semangat kepada siswanya agar dapat meraih kesuksesan dan terjadi pengingkatan dalam kualitas belajar siswanya.

Hasil observasi aktivitas siswa dalam mengisi daftar hadir dan mengumpulkan tugas secara tepat waktu dari siklus 1 ke siklus 2 seperti disajikan pada Grafik 1, dan Grafik 2 sudah menunjukkan target keberhasilan penelitian yakni adanya peningkatan aktivitas siswa dalam mengisi daftar hadir atau dalam kelas tatap muka merupakan kehadiran siswa di kelas secara tepat waktu, dan peningkatan siswa yang mengumpulkan tugas tepat waktu. Hal ini terkait peran guru dalam pembelajaran, dimana guru merupakan fasilitator dan motivator. Setelah guru memotivasi siswa selama pembelajaran berlangsung, siswa secara metakognitif menginstruksikan diri untuk mengatur kinerja dalam menyelesaiakan tugas (Muhali, 2018). Peran guru sebagai motivator secara terus menerus menumbuhkan motivasi siswa untuk hadir di kelas maya dan mengumpulkan tugas secara tepat waktu. Siswa dapat memperoleh pengetahuan (deklaratif, procedural, dan kondisioal) melalui sejumlah keterampilan tertentu dan ditunjukkan dengan aktivitas secara langsung serta keseluruhan, proses tersebut yang dilakukan secara sadar (Asy'ari, Ikhsan, \& Muhali, 2019; Muhali, 2017).

\section{SIMPULAN}

Berdasarkan hasil observasi dan pembahasan menunjukkan bahwa pembelajaran menggunakan media google classroom dapat merekam aktivitas siswa dan aktivitas guru selama PJJ berlangsung. Hal tersebut ditunjukkan bahwa terjadi peningkatan aktivitas siswa dalam mengisi daftar hadir dengan tepat waktu sebesar $61 \%$ kategori sedang pada siklus 1 meningkat menjadi 75\% pada siklus 2 dengan kategori tinggi. Aktivitas siswa mengumpulkan tugas atau penilaian secara tepat waktu meningkat dari $64 \%$ menjadi $80 \%$ pada siklus 2 dengan kategori tinggi, sedangkan aktivitas guru pada siklus 1 sebesar $82 \%$ dengan kategori tinggi, meningkat menjadi 95\% pada siklus 2 dengan kategori sangat tinggi. Jadi, penggunaan media google classroom dalam PJJ dapat merekam aktivitas siswa dengan kategori tinggi dan aktivitas guru dengan kategori sangat tinggi.

\section{DAFTAR PUSTAKA}

Asy'ari, M., Ikhsan, M., \& Muhali. (2019). The Effectiveness of inquiry learning model in improving prospective teachers' metacognition knowledge and metacognition awareness. International Journal of Instruction, 12(2), 455-470. https://doi.org/https://doi.org/10.29333/iji.2019.12229a

Hamalik, O. (2002). Proses belajar mengajar. Jakarta: Bumi Aksara.

Hasmiati, J., \& Mustami. (2017). Aktivitas dan hasil belajar siswa pada pembelajaran pertumbuhan dan perkembangan dengan metode praktikum. Jurnal Biotek, 5(1), 21-35.

Muhali. (2017). Conceptual framework of reflective-metacogtitive learning model to improve students' metacognition ability at senior high school. Proceeding of Mathematic, Informatic, Science, and Education International Conference. Surabaya: Universitas Negeri Surabaya. Indonesia.

Muhali. (2018). Pengembangan model pembelajaran reflektif-metakognitif untuk meningkatkan kemampuan metakognisi siswa SMA. Universitas Negeri Surabaya. 
Musriana. (2019). Pengaruh guru sebagai motivator terhadap hasil belajar siswa pada mata pelajaran akutansi kelas IPS di SMA Negeri 12 Makasar. Universitas Negeri Makassar.

Nurfayanti, \& Nurbaeti. (2019). Pengaruh media pembelajaran google classroom dalam pembelajaran analisis real terhadap motivasi belajar mahasiswa. Proximal: Jurnal Penelitian Matematika dan Pendidikan Matematika, 2(1), 50-59. https://doi.org/https://doi.org/10.30605/2615-7667.211

Purwanto. (2010). Evaluasi hasil belajar. Yogyakarta: Pustaka Pelajar.

Rahmanto, M. A., \& Bunyamin. (2020). Efektifitas pembelajaran daring melalui google classroom. Jurnal Pendidikan Islam, 11(2), 119-135.

Rusman. (2010). Model-model pembelajaran mengembangkan profesionalisme guru. Jakarta: Rajawali Press.

Rusman. (2015). Pembelajaran tematik terpadu: teori, praktik, dan penilaian. Jakarta: PT. Raja Grafindo Persada.

Sabran, \& Subara. (2019). Keefektifan google classroom sebagai media pembelajaran. Prosiding Seminar Nasional Lembaga Penulisan Universitas Negeri Makasar, 122125. Retrieved from https://webcache.googleusercontent.com/search?q=cacher:SS_KKM_r2TAJ:https:/ /ojs.unm.ac.id/semnaslemlit/article/download/8256/4767+\&cd=2\&h1=id\&ct=cl nk\&g1=id

Sardiman, A. M. (2003). Interaksi dan motivasi belajar mengajar. Jakarta: PT. Raja Grafindo Persada.

Sutrisna, D. (2018). Meningkatkan kemampuan literasi mahasiswa menggunakan google classroom. FON : Jurnal Pendidikan Bahasa Dan Sastra Indonesia, 13(2), 69-78. https://doi.org/https://doi.org/10.25134/fjpbsi.v13i2.1544 